\title{
Factors associated with poor sleep quality among HIV-positive individuals in Mexico City
}

\author{
Evelyn Rodríguez Estrada, Maria Candela Iglesias Chiesa, ${ }^{1}$ Ana Fresán Orellana, ${ }^{2}$ Gustavo Reyes-Terán'
}

\begin{abstract}
Centro de Investigación en Enfermedades Infecciosas, Instituto $\mathrm{Na}$ cional de Enfermedades Respiratorias, Ciudad de México, México.

2 Subdirección de Investigaciones Clínicas, Instituto Nacional de Psiquiatría Ramón de la Fuente Muñiz, Ciudad de México, México.
\end{abstract}

\section{Correspondence:}

Evelyn Rodríguez-Estrada

Centro de Investigación en Enfermedades Infecciosas, Instituto Nacional de Enfermedades Respiratorias, Ciudad de México, México.

Calzada Tlalpan 4502, Sección XVI, Tlalpan, C.P. 14080 Ciudad de México, México.

Phone: 015556667985

Email: evelyn.rodriguez@cieni.org.mx

Received: 30 Enero 2018

Accepted: 9 Mayo 2018

Citation:

Rodríguez-Estrada, E., Iglesias-Chiesa, M. C., Fresán-Orellana, A., ReyesTerán, G. Factors associated with poor sleep quality among HIV-positive individuals in Mexico City. Salud Mental, $41(3)$, 123-129. doi: $10.17711 /$ SM.0185-3325.2018.016

\section{(c) (i) (5)}

\begin{abstract}
Introduction. Sleep quality is commonly impaired in medical disorders, and the HIV-positive population is particularly vulnerable to complaint from sleep disturbances. Objective. To determine the prevalence of poor sleep quality and the factors associated with it, in a population of HIV positive Mexican out patients. Method. A cross sectional study was done. A sample of 367 HIV-positive subjects over 18 years completed a set of self-administered questionnaires: the Pittsburgh Sleep Quality Index (PSQI), the Epworth Sleepiness Scale, the Athens Insomnia Scale, and the Beck Depression Inventory. Sociodemographic and clinical data were recorded. Results. Of the respondents, $82.8 \%(n=304)$ were male. The mean age of the patients was $36.6(S D=9.4)$ years, and the mean educational level was $12.2(S D=3.8)$ years. According to the PSQI, $58.6 \%(n=215)$ had poor sleep quality. Poor sleep quality was more common in those who had lived longer with HIV, had started their antiretroviral treatment later, had suboptimal antiretroviral adherence, had a CD4 cell count $<200$ cells/ $\mu \mathrm{L}$, reported illicit drug use, had concomitant medications, or had insomnia, sleepiness, or depressive symptoms. In multivariate analyses, poor sleep quality was associated with depressive symptoms, illicit drug use, a CD4 count $<200$ cells $/ \mu \mathrm{L}$, and time elapsed since HIV diagnosis. Discussion and conclusion. Poor sleep quality is common in HIV patients. Early identification of patients with poor sleep quality through vigilance for factors associated with it might facilitate prompt treatment.
\end{abstract}

Keywords: HIV infection, depression, sleep quality.

\section{RESUMEN}

Introducción. La población seropositiva es particularmente vulnerable a presentar alteraciones del sueño. Objetivo. Determinar la prevalencia y los factores asociados a la mala calidad del sueño en un grupo de pacientes con VIH en la Ciudad de México. Método. Estudio transversal. Se incluyó una muestra de 367 personas con VIH mayores de 18 años. Todos los pacientes contestaron el Índice de Calidad del Sueño de Pittsburgh (PSQI), la Escala de Somnolencia de Epworth, la Escala de Atenas de linsomnio y el Inventario de Depresión de Beck. Se recabaron datos sociodemográficos y clínicos. Resultados. El $82.8 \%(n=304)$ de los encuestados eran varones. La edad media fue de $36.6(D E=9.4)$, con escolaridad promedio de 12.2 $(D E=3.8)$ años. El $58.6 \%(n=215)$ tuvieron una mala calidad del sueño. La mala calidad del sueño fue más común en aquellos con mayor tiempo de haber sido diagnosticados, con mayor retardo en el inicio y adherencia subóptima al tratamiento antirretroviral, con recuento de linfocitos T-CD $4^{+}<200$ células $/ \mu \mathrm{L}$, con uso ilícito de drogas y uso de medicamentos concomitantes, o con presencia de insomnio, somnolencia y síntomas depresivos. En el análisis multivariado, la mala calidad del sueño se asoció con síntomas depresivos, uso de drogas ilícitas, un recuento de linfocitos $\mathrm{T}-\mathrm{CD} 4^{+}<200$ células/ $\mu \mathrm{L}$ y el tiempo desde el diagnóstico de VIH. Discusión y conclusión. La mala calidad del sueño es común en pacientes con VIH. Su identificación temprana a través de la vigilancia de los factores asociados con ella puede facilitar el tratamiento oportuno.

Palabras clave: $\mathrm{VIH}$, depresión, calidad del sueño. 


\section{INTRODUCTION}

Sleep quality is an indicator of wellbeing. Poor sleep quality is associated with increased co-morbidity, mortality, and healthcare costs and decreased quality of life ("Garbarino, Lanteri, Durando, Magnavita, \& Sannita, 2016"), both in clinical populations (Koren, Dumin, \& Gozal, 2016) and in the general population (Hayashino et al., 2010). Sleep quality is commonly impaired in medical disorders (Berry \& Harding, 2004). In particular, sleep disturbances have been recognized in people with HIV since the early days of the epidemic (Norman et al., 1992). The prevalence of poor sleep quality in the HIV-positive population ranges from $40 \%$ to $100 \%$ (Wu, Wu, Lu, Guo, \& Li, 2015) as compared to $13 \%$ to $30 \%$ in the general population (Knutson, 2015).

Patients with HIV/AIDS are particularly vulnerable to poor sleep quality because of multiple biological factors. These factors include central nervous system (CNS) HIV-involvement, opportunistic infections of the CNS, substance use, antiretroviral (ARV) side effects, medical comorbidity, and immune dysfunction (Irwin, Olmstead, \& Carroll, 2016). The prevalence of poor sleep quality does not change in the context of highly effective ARV therapy and controlled viral replication, indicating that it may be attributable to factors other than HIV disease (Allavena et al., 2016). Other factors contributing to poor sleep quality in people with HIV include psychosocial distress, gender, employment status, negative lifestyle habits, and psychiatric comorbidity (Garbarino et al., 2016).

Poor sleep quality is associated with several adverse consequences in the HIV-infected population. These consequences include impact on ART adherence, decreased engagement in HIV-care, diminished health-related quality of life, excessive daytime sleepiness, and cognitive impairment (Tedaldi, Minniti, \& Fischer, 2015; Tello-Velasquez et al., 2015; Vosvick et al., 2004).

In Mexico, the prevalence of poor sleep quality in the general population ranges from $21 \%$ (Jordan, Perez-Escamilla, Desai, \& Shamah-Levy, 2016) to 26\% (Cabada-Ramos, Cruz-Corona, Pineda-Murguía, Sánchez-Camacho, \& Solano-Heredia, 2015). To our knowledge, to date no estimation of sleep quality has been carried out in HIV-positive Mexican patients. The aim of this study therefore was to determine the prevalence of poor sleep quality in HIV-positive Mexican out-patients, and to identify associated factors.

\section{METHODS}

A cross-sectional study was conducted at the Centro de Investigación en Enfermedades Infecciosas (CIENI) of the Instituto Nacional de Enfermedades Respiratorias (INER) in Mexico City. A random sample was obtained from June 2012 to June 2013 from HIV-positive patients, aged 18-59 years, attending the Laboratory of Virological Diagnosis (LVD) - CIENI. The LVD is a national reference laboratory to determine HIV viral load (VL) and CD4 T cell counts (VL was performed by automated real-time PCR in the m2000 equipment -Abbott, Abbott Park, IL-; CD4 T cell counts were carried out by flow cytometry with the Trucount reaction time in a FACS Calibur device -BD Biosciences, San José, CA-). A random list of 10 numbers was generated each day using Excel (Microsoft Office 2016 for Mac) from numbers 1 to 200. Patients who had the appointment number corresponding to the random selection made were invited to participate.

Patients answered a set of self-administered instruments on sleep quality, sleepiness, insomnia, and depressive symptoms. Sociodemographic data, substance use, data on concomitant medications, current antiretroviral (ARV) therapy, and self-reported ARV adherence were obtained by direct interview (adherence was categorized as optimal when patients had $>95 \%$ ARV intake within the last week). HIV viral load and CD4 T cell counts were obtained from LVD results. To diminish the possibility that some respondents might not have fully understood the questions used, an interviewer was present at all evaluations, provided detailed instructions, and remained close by to answer any questions from the respondents.

A total sample size of 369 participants was calculated using the formula to estimate a proportion (Daniel, 1999) based on an expected prevalence of $40 \%$ of poor sleep quality for HIV-positive persons, with a level of confidence of $95 \%$ and a precision of $.5 \%$. The protocol was approved by the INER's Ethical and Scientific Board.

\section{Measures}

The instruments used were the Pittsburgh Sleep Quality Index (PSQI), the Epworth Sleepiness Scale, the Athens Insomnia Scale, and the Beck Depression Inventory. Sleep quality was assessed by using the PSQI in a validated Mexican version (reliability coefficient $=.78)$ (Jiménez-Genchi, Monteverde-Maldonado, Nenclares-Portocarrero, \& Esquivel-Adame, 2008). The PSQI is the most widely validated instrument used in research and clinical settings to assess global sleep quality in HIV-infected individuals (Wu et al., 2015). The PSQI is a 19-item self-rated scale which assesses sleep quality and disturbances over a 1 month time interval, assessing seven sleep components: sleep quality, sleep latency, sleep duration, habitual sleep efficiency, sleep disturbances, use of hypnotics, and daytime dysfunction during the last month. The global PSQI score is then calculated by totaling the seven component scores, providing an overall score ranging from 0 to 21 . A score $>5$ points denoted poor sleep quality (Buysse, Reynolds, Monk, Berman, \& Kupfer, 1989). Clinical studies have found the PSQI to be reliable and valid to assess 
sleep quality, but have found weak or inconsistent associations between the PSQI and objective measures, such as polysomnography or actigraphy (Buysse et al., 2008; Krystal \& Edinger, 2008).

We used the Epworth Sleepiness Scale (ESS), in a validated Mexican version (Sandoval-Rincón, Alcala-Lozano, Herrera-Jiménez, \& Jiménez-Genchi, 2013), identify daytime sleepiness (reliability $=.89$ ). ESS scores range from 0 to 24. Scores higher than nine points defined daytime sleepiness. A score between 10-12 points identifies mild and $>12$ points indicates excessive daytime sleepiness (Johns, 1991).

The Athens Insomnia Scale (AIS) is an 8-item questionnaire that identifies non-organic insomnia according to the International Classification of Diseases 10th Revision (ICD - 10) criteria (Soldatos, Dikeos, \& Paparrigopoulos, 2000), Scores of six points or higher indicate insomnia (Portacarrero \& Genchi, 2005; Soldatos, Dikeos, \& Paparrigopoulos, 2003).

The Mexican validated version (Jurado et al., 1998) of the Beck Depression Inventory $(\mathrm{BDI})$ (reliability $=.90$ ) was used to identify depressive symptoms. The BDI has 21 items, each answer is scored on a scale value of 0 to 3 . A score over nine points identifies mild, 19-29 points moderate, and $\geq 30$ points severe depressive symptoms. The Mexican version of the BDI has been shown to be of good diagnostic utility, both in the general population and in individuals with HIV infection (Rodriguez et al., 2012).

\section{Statistical Analysis}

Demographic and clinical characteristics were described using frequencies and percentages for categorical variables as well as means and standard deviations for the continuous variables. The chi square test, U- Mann-Whitney test, and the Student's t test were used for comparison between groups as appropriate. The significance level for all the analyses was established at $p<.05$ (2-tailed). Multivariate logistic regression was used for the calculation of the likelihood that poor sleep quality would occur. To perform this analysis variables included were classified as auxiliary binary variables (represented by 0 as the no-risk value and 1 as the risk value) according to a dummy codification. The Akaike Information Criterion (AIC) was used to determine which of the candidate models best approximated the data (Hastie, Tibshirani, \& Friedman, 2009). The model with the lower AIC value is considered to be superior, although there are no defined thresholds associated with this measure. We analyzed our data using the statistical software package SPSS version 20.0 for Windows PC.

\section{Ethical considerations}

All invited participants filled out the self-administered instruments while waiting for their medical appointment, at
CIENI's waiting room between 7:00 - 13:00 hours and provided written consent. Incomplete questionnaires were not included in the analysis.

\section{RESULTS}

From June 2012 to June 2013, 374 HIV-positive outpatients were enrolled in the study. Seven were eliminated because they provided incomplete questionnaires; thus, 367 were included in the final analysis (Table 1). Mean age was 36.6 years, and mean educational level was 12.1 years (equivalent to completion of high school). Most subjects were male, single, and employed.

The participants had been living knowing they were HIV infected for an average of 5.3 years and had started ARV treatment with an average delay time of 12.9 months after diagnosis. Most subjects $(n=315,85.8 \%)$ were under ARV

Table 1

Sample characteristics

\begin{tabular}{|c|c|}
\hline & $\begin{array}{c}\text { Total sample } \\
N=367\end{array}$ \\
\hline Age (years) [mean, $(S D)]$ & $36.6(9.8)$ \\
\hline Sex (male) $[n(\%)]$ & $304.0(83.8)$ \\
\hline Single marital status $[n(\%)]$ & $269.0(73.3)$ \\
\hline Educational level (years) [mean, $(S D)]$ & $12.1(3.6)$ \\
\hline Currently employed $[n(\%)]$ & $247.0(67.3)$ \\
\hline BMI [mean, $(S D)]$ & $23.7(3.9)$ \\
\hline Illicit drug use ${ }^{1}[n(\%)]$ & $76.0(20.7)$ \\
\hline Alcohol use $[n(\%)]$ & $205.0(55.9)$ \\
\hline Caffeine use $[n(\%)]$ & $219.0(59.7)$ \\
\hline Nicotine use $[n(\%)]$ & $89.0(24.3)$ \\
\hline Years since HIV diagnosis [mean, $(S D)$ ] & $5.3(5.4)$ \\
\hline Duration of ART (years) [mean, $(S D)]$ & $4.6(4.9)$ \\
\hline Delay in starting ART (months) [median, (IQR)] & $2.0(.8)$ \\
\hline Current ART $[n(\%)]$ & $315.0(85.8)$ \\
\hline EFV-based ART $[n(\%)]$ & $195.0(53.1)$ \\
\hline Last-week ART adherence rate < 95\% $[n(\%)]$ & $66.0(21)$ \\
\hline Additional medications & $153.0(41.9)$ \\
\hline \multicolumn{2}{|l|}{ CD4 cell count $(n=362)$} \\
\hline$<200 \mathrm{cells} / \mu \mathrm{L}$ & $74.0(20.4)$ \\
\hline$\geq 200 \mathrm{cells} / \mu \mathrm{L}$ & $287.0(78.1)$ \\
\hline \multicolumn{2}{|l|}{ Plasma HIV-1 RNA [n (\%)] } \\
\hline$<40$ copies $/ \mathrm{ml}$ & $239.0(65.1)$ \\
\hline$>40$ copies $/ \mathrm{ml}$ & $128.0(34.9)$ \\
\hline $\operatorname{AIS}[n(\%)]$ & $94.0(25.6)$ \\
\hline \multicolumn{2}{|l|}{$\mathrm{DBI}[n(\%)]$} \\
\hline $10-18$ points & $76.0(20.7)$ \\
\hline $19-29$ points & $51.0(13.9)$ \\
\hline$\geq 30$ points & $27.0(7.4)$ \\
\hline \multicolumn{2}{|l|}{$\operatorname{ESS}[n(\%)]$} \\
\hline $10-12$ points & $26.0(7.1)$ \\
\hline$>12$ points & $25.0(6.8)$ \\
\hline
\end{tabular}


Table 2

Comparison of HIV-positive outpatients having good and poor sleep quality

\begin{tabular}{|c|c|c|c|c|c|c|c|}
\hline \multirow[b]{3}{*}{ Overall $[n(\%)]$} & \multicolumn{4}{|c|}{ Sleep Quality } & \multirow{2}{*}{\multicolumn{2}{|c|}{$\begin{array}{l}\text { Odds ratio } \\
(95 \% \mathrm{Cl})\end{array}$}} & \multirow{3}{*}{$P$ value } \\
\hline & \multicolumn{2}{|c|}{ Good } & \multicolumn{2}{|c|}{ Poor } & & & \\
\hline & 152.0 & $(41.4)$ & 215.0 & $(58.6)$ & & & \\
\hline Age (years) [mean, $(S D)]$ & 35.5 & $(9.2)$ & 37.3 & $(9.5)$ & & - & .075 \\
\hline Sex $(\%$ male $)$ & 173.0 & $(80.5)$ & 131.0 & $(86.2)$ & & - & .152 \\
\hline Single & 113.0 & $(74.3)$ & 156.0 & $(72.6)$ & & - & .704 \\
\hline Educational level (years) [mean, $(S D)]$ & 12.1 & $(3.6)$ & 12.3 & $(3.9)$ & & - & .576 \\
\hline Currently employed & 110.0 & $(72.4)$ & 137.0 & $(63.7)$ & & - & .082 \\
\hline BMI [mean, $(S D)]$ & 23.6 & $(3.7)$ & 23.7 & $(4.1)$ & & - & .794 \\
\hline Illicit drug use ${ }^{a}[n(\%)]$ & 22.0 & $(14.5)$ & 54.0 & $(25.1)$ & 1.9 & $(1.2-3.4)$ & $.013^{*}$ \\
\hline Alcohol use $[n(\%)]$ & 81.0 & $(53.3)$ & 124.0 & $(57.7)$ & & - & .405 \\
\hline HIV diagnosis $>4$ years $^{\mathrm{b}}[n(\%)]$ & 50.0 & (32.9) & 102.0 & $(47.4)$ & 1.8 & $(1.2-2.8)$ & $.005^{*}$ \\
\hline Duration of ART (years) [mean, $(S D)]$ & 4.2 & $(4.6)$ & 5.0 & $(5.0)^{\prime}$ & & - & .151 \\
\hline $\begin{array}{l}\text { Delay in starting ART }>2 \text { months }^{\mathrm{a}} \\
\text { [median, (IQR)] }\end{array}$ & 1.0 & $(0,5)$ & 3.0 & $(0,12)$ & 1.8 & $(1.2-2.7)$ & $.003^{*}$ \\
\hline Current ART $[n(\%)]$ & 129.0 & $(85.4)$ & 186.0 & $(86.5)$ & & - & .769 \\
\hline EFV based ART $[n(\%)]$ & 86.0 & $(56.6)$ & 109.0 & $(50.7)$ & & - & .266 \\
\hline ART adherence rate $<95 \%^{\mathrm{c}}[n(\%)]$ & 20.0 & $(15.5)$ & 46.0 & $(24.7)$ & 1.78 & $8(1.0-3.2)$ & $.048^{*}$ \\
\hline Use of additional medications & 48.0 & $(31.8)$ & 105.0 & $(49.1)$ & 2.1 & $(1.3-3.1)$ & $.001^{*}$ \\
\hline CD4 cell count $<200$ cells $/ \mu \mathrm{L}$ & 23.0 & $(15.1)$ & 52.0 & $(24.8)$ & 1.8 & $(1.0-3.2)$ & $.026^{*}$ \\
\hline Detectable viral load ${ }^{d}[n(\%)]$ & 106.0 & $(69.7)$ & 133.0 & $(61.9)$ & & - & .122 \\
\hline Insomnia ${ }^{\mathrm{e}}[n(\%)]$ & 1.0 & $(.7)$ & 93.0 & $(43.3)$ & 115.0 & $(15-837)$ & $<.001^{\star}$ \\
\hline Depressive symptoms ${ }^{f}[n(\%)]$ & 24.0 & $(15.8)$ & 130.0 & $(60.5)$ & 8.2 & $(4.8-13.6)$ & $<.001^{*}$ \\
\hline Sleepiness ${ }^{g}[n(\%)]$ & 14.0 & $(9.2)$ & 37.0 & $(17.2)$ & 2.0 & $(1.1-3.9)$ & $.029^{*}$ \\
\hline
\end{tabular}

treatment at the time of evaluation, of which $59 \%(n=186)$ were on their first ARV regimen, $27.3 \%(n=86)$ on their second, $6.7 \%(n=21)$ on their third, and $7 \%(n=22)$ on their fourth or more ARV regimen. Last-week adherence was reported as optimal ( $>95 \%$ adherence) for $79 \%(n=249)$, half had current EFV-based ARV regimens (with any drug combination used as backbone). Median CD4 T cell count was 413 cells $/ \mu \mathrm{L}$ (interquartile range (IQR) $234-565$ cells $/ \mu \mathrm{L}$ ), and 239 subjects $(65.1 \%)$ had an undetectable viral load (plasma HIV-1 RNA > 40 copies/ml). Forty-two percent were taking additional medications (median $=1$ additional medication, range $=1-9$ ).

According to BDI score, $42 \%$ of patients had depressive symptoms; intensity was mild in $20.7 \%$, moderate in $13.9 \%$, and severe in $7.4 \%$. A quarter of the subjects had insomnia (based on AIS) and $13.9 \%$ had sleepiness, which was marginal for $7.1 \%$ and excessive for $6.8 \%$ of the sample.

Poor sleep quality was reported by $58.6 \%$ of our sample (Table 2). In an univariate analysis, poor sleep quality was significantly more common in those who had lived longer with HIV, had longer delays in starting their antiretroviral treatment, had suboptimal ARV adherence, had lower CD4 cell counts $(<200$ cells $/ \mu \mathrm{L})$, were taking additional medications, had illicit substance use, or had insomnia, sleepiness, and depressive symptoms, as measured by the clinimetric evaluation. There were no differences between groups in nicotine and caffeine intake (nicotine, $\chi^{2}=2.600$, $p=.107$; caffeine, $\left.\chi^{2}=.019, p=.891\right)$ and current number of ARV regimen $\left(\chi^{2}=6.376, p=.095\right)$. The number of additional medications did not correlate with PSQI scores $(r=.018, p=.831)$. Poor sleepers tended to have higher scores on all PSQI components (Table 3 ).

Two multivariate logistic regression models were created to determine the predictors of poor sleep quality among the study population (Table 4). The first model included all significant nine variables: illicit drug use, time since HIV

Table 3

Pittsburgh sleep quality index subcomponents scores in HIV-positive outpatients with good and poor sleep quality

\begin{tabular}{lrrr}
\hline & \multicolumn{3}{c}{ Sleepers } \\
\cline { 2 - 4 } & Good $(n=152)$ & Poor $(n=215)$ \\
\hline PSQI 1 (subjective sleep quality) & $.6(.5)$ & $1.5(.7)$ \\
PSQI 2 (sleep latency) & $.6(.7)$ & $1.9(1.0)$ \\
PSQI 3 (sleep duration) & $.4(.6)$ & $1.5(.9)$ \\
PSQI 4 (sleep efficiency) & $.2(.5)$ & $1.6(1.2)$ \\
PSQI 5 (sleep disturbances) & $1.0(.5)$ & $1.6(.6)$ \\
PSQI 6 (use of sleep medication) & $.1(.4)$ & $.7(1.1)$ \\
PSQI 7 (daytime dysfunction) & $.5(.6)$ & $1.6(.9)$ \\
Total PSQI & $3.6(1.4)$ & $10.1(3.6)$ \\
\hline
\end{tabular}

Note: PSQI, Pittsburgh Sleep Quality Index. Values are means (with standard deviations in parenthesis). 
Table 4

Multivariate logistic regression models for poor sleep quality among HIV-positive outpatients $(n=367)$

\begin{tabular}{|c|c|c|c|c|}
\hline & $\begin{array}{c}\text { First model }^{+} \\
\text {Adjusted odds ratio } \\
(95 \% \mathrm{Cl})\end{array}$ & $P$ value & $\begin{array}{l}\text { Second model }{ }^{++} \\
\text {Adjusted odds ratio } \\
(95 \% \mathrm{Cl})\end{array}$ & $P$ value \\
\hline HIV diagnosis $>4$ years $^{a}$ & $1.57(.86-2.89)$ & .140 & $1.79(1.05-3.08)$ & $.032^{*}$ \\
\hline Delay in starting ART > 2 months ${ }^{a}$ & $1.28(.71-2.31)$ & .413 & $1.56(.91-2.65)$ & .099 \\
\hline ART adherence rate ${ }^{b}<95 \%{ }^{\text {b }}$ & $1.70(.83-3.48)$ & 147 & $1.37(.70-2.69)$ & .355 \\
\hline CD4 cell count $<200$ cells $/ \mu \mathrm{L}$ & $1.94(.88-4.33)$ & .102 & $2.19(1.10-4.33)$ & $.025^{\star}$ \\
\hline Use of additional medications & $1.17(.63-2.19)$ & .609 & - & \\
\hline Illicit drug use ${ }^{c}$ & $2.05(1.01-4.02)$ & $.048^{*}$ & $1.98(1.00-3.91)$ & $.050^{*}$ \\
\hline Insomnia ${ }^{d}$ & $1.18+E 9$ & .996 & - & \\
\hline Depressive symptoms ${ }^{e}$ & $321 \quad(1.74-5.96)$ & $<.001^{*}$ & $6.11(3.5-10.62)$ & $<.001^{*}$ \\
\hline Sleepiness ${ }^{f}$ & $1.34(.52-3.41)$ & .543 & - & \\
\hline
\end{tabular}

Note: a Mean and median cut-off points were used to categorize variables. ${ }^{\mathrm{b}} \mathrm{ARV}$ adherence within last 7 days. ${ }^{\mathrm{C}} \mathrm{Cannabis}$ cocaine, amphetamines. ${ }^{\mathrm{d} A I S}$ score $\geq 6$ points. ${ }^{\mathrm{e} B D I}>9$ points. ${ }^{\mathrm{f}} \mathrm{ESS}>9$ points. EFV, Efavirenz; ART, Antiretroviral treatment. ${ }^{+} \chi^{2}=141.140$, Nagelkerke $=.492 ;{ }^{++} \chi^{2}=76.454$, Nagelkerke $=.294$

diagnosis, delay in ART initiation after diagnosis, ART adherence, additional medications, lymphocyte CD4 cell count $<200$ cell $/ \mu \mathrm{L}$, insomnia, sleepiness, and depressive symptoms. Depression and illicit drug use were significant predictors in the model.

The second model did not include the variables of insomnia, additional medications, and sleepiness because they were the least related variables in the first model (Table 4). Both models had an adequate prediction (Nagelkerke, $R^{2}$ ) and were valid (Hosmer). They identified more than $72 \%$ of the subjects with poor sleep quality. The adequacy of the second model was corroborated by a reduction in AIC values from 166.85 to 115.11 . Having lived with HIV for longer time ( $>4$ years), having CD4 cell counts $<200$ cell/ $\mu \mathrm{L}$, taking illicit drugs, and reporting depressive symptoms significantly predicted poor sleep quality.

\section{DISCUSSION AND CONCLUSION}

We found a high prevalence of poor sleep quality (58.9\%) in HIV-infected individuals in agreement with results reported by Oshinaike et al. (2014) in Nigeria (59.3\% prevalence). Poor sleep quality was linked to a higher score in most PSQI components, indicating the complexity of the problem. It was previously reported that the prevalence of poor sleep quality in the HIV-positive population ranged from $40 \%$ to $100 \%$ (Wu et al., 2015). These differences in prevalence may be due to various factors including differences in geographical area, characteristics of participants, and measurement instruments among studies. In Mexico, prevalence of poor sleep quality in the general population ranges from $21 \%$ (Jordan et al., 2016) to $26 \%$ (Cabada-Ramos et al., 2015). Our study demonstrates that poor sleep quality is more common in the Mexican HIV population than in the general Mexican population.
We found that poor sleep quality was predicted by depressive symptoms, illicit drug use, CD $<200$ cell $/ \mu \mathrm{L}$, and longer time since HIV diagnosis. Depression has been consistently associated with poor sleep quality in different clinical populations (Hayashino et al., 2010), including HIV-positive patients (Wibbeler, Reichelt, Husstedt, \& Evers, 2012). High prevalence of poor sleep quality in HIV-infected patients with depressive symptoms also has been found by others (Allavena et al., 2016; Huang et al., 2017; Oshinaike et al., 2014). In our study, the prevalence of depressive symptoms $(42 \%)$ was lower than that of poor sleep quality (58.9\%), suggesting the importance of distinguishing poor sleep quality caused by depression from that resulting from other causes.

In our study, length of time since HIV diagnosis was linked to poor sleep quality. This may be related to the immunoinflammatory system changes (Irwin et al., 2016) seen in HIV-infected patients. Alterations in the inflammatory response are associated with HIV infection, even in those with undetectable viral load. CNS inflammation occurs secondary to HIV-proteins (for example, Tat protein), even in the absence of active viral replication (Chauhan et al., 2003). Elevated circulating proinflammatory cytokines modify the activity of many regions of the brain to affect sleep, including the autonomic regulatory centers, hypothalamus, limbic system, mesolimbic cortex, and brainstem nuclei (Lorton et al., 2006). This relationship of inflammation and sleep quality has been demonstrated also in healthy individuals (Foster et al., 2012).

We found an association of low CD4 cell counts $(<200$ cells $/ \mu \mathrm{L}$ ) and poor sleep quality. Previous findings regarding the relationship between CD4 cell counts and sleep quality have been inconsistent (Wu et al., 2015), with some studies supporting the association (Dabaghzadeh, Khalili, Ghaeli, \& Alimadadi, 2013; Oshinaike et al., 2014) and others not (Allavena et al., 2016; Huang et al., 2017). Patients with 
lymphocyte CD 4 cell counts $<200$ cells/ $\mu \mathrm{L}$ are by definition in the AIDS stage, which is associated with greater medical comorbidity. Sleep quality declines linearly as the number of comorbid medical conditions increases, independent of depressive status (Hayashino et al., 2010).

Illicit drug use is independently associated with sleep disturbances in persons without HIV infection (Mahoney et al., 2014). Most studies focusing on sleep quality in HIV-infected individuals do not include illicit drug use among the variables recorded. Our study is one of the few (Saberi, Neilands, \& Johnson, 2011) to associate illicit drug use with poor sleep quality. This may be a manifestation of the additive deleterious effects of HIV and illicit substance use on the CNS (Strazza, Pirrone, Wigdahl, \& Nonnemacher, 2011).

Sleep quality includes quantitative and subjective wellbeing and daytime functioning. In our study, poor sleep quality was reported more frequently than insomnia and somnolence. This highlights the relevance that sleep quality should be routinely assessed in HIV-infected people regardless of insomnia and somnolence presence.

Our study had some limitations. We did not evaluate other sleep disturbances such as sleep-related apnea, hypersomnia, narcolepsy, or restless legs syndrome which can influence sleep quality and produce sleepiness. The participants' chronotype aspects, day-night activity levels, and presence of anxious symptoms were not included in the variables measured, but all of them might impact sleep quality. We did not specify the subtypes of additional medications and illicit drug use in our sample. Future sub-classification is needed to evaluate the influence of particular substances in sleep quality. Additionally, the PSQI is a broad subjective measure intended to assess several domains of sleep; thus, it might over or underestimate certain sleep parameters relative to objective measures of sleep, such as polysomnography or actigraphy (Krystal \& Edinger, 2008). Other psychological aspects that might influence sleep quality were not measured, such as disease acceptance and treatment related distress. However, in our study most patients had undetectable viral load and had known to be living with HIV a mean of 5.3 years, diminishing the probability of these factors to be present in our sample considering as a proxy of disease acceptance and treatment related distress.

Strengths of the study include the completion of all questionnaires the day the patients underwent their laboratory test, thus permitting a robust link between CD4 cell counts and sleep quality, and the inclusion of illicit drug use in the variables recorded from participants. We diminished selection bias by using a random selection of participants. Even though we did not specifically address nightmares or vivid dreams, which are frequently reported by patients on EFV-based ARV regimens, the PSQI evaluates in one item the presence of bad dreams. This item was not statistical different between poor and good sleep quality groups, nor between EFV-based and non EFV-based ARV regimens (Table 2).

Poor sleep quality is common in Mexican HIV patients. Multiple factors are associated with it, and early identification might facilitate prevention strategies and prompt treatment of poor sleep quality in HIV- positive patients. Our findings provide new insight into the association between poor sleep quality and a profile of risk factors in HIV-infected individuals. These risk factors may play a role in both pro-inflammatory and mental health aspects. Future research is required to determine the pathophysiology of poor sleep quality and other sleep disturbances in HIV-positive people to potentially allow more effective prevention and treatment of these problems.

\section{Funding}

None.

\section{Conflict of interests}

The authors declare they have no conflict of interests.

\section{REFERENCES}

Allavena, C., Guimard, T., Billaud, E., De la Tullaye, S., Reliquet, V., Pineau, S., ... Hiloto, H. (2016). Prevalence and risk factors of sleep disturbance in a large HIV-infected adult population. AIDS and Behavior, 20(2), 339-344.

Berry, R. B.\& Harding, S. M. (2004). Sleep and medical disorders. Medical Clinics, 88(3), 679-703, ix. doi: 10.1016/j.mcna.2004.01.006

Buysse, D. J., Reynolds, C. F., Monk, T. H., Berman, S. R., \& Kupfer, D. J. (1989). The Pittsburgh Sleep Quality Index: a new instrument for psychiatric practice and research. Psychiatry Research, 28(2), 193-213.

Buysse, D. J., Hall, M. L., Strollo, P. J., Kamarck, T. W., Owens, J., Lee, L., ... Matthews, K. A. (2008). Relationships between the Pittsburgh Sleep Quality Index (PSQI), Epworth Sleepiness Scale (ESS), and clinical/polysomnographic measures in a community sample. Journal of clinical sleep medicine: JCSM: official publication of the American Academy of Sleep Medicine, 4(6), 563-571.

Cabada-Ramos, E., Cruz-Corona, J., Pineda-Murguía, C., Sánchez-Camacho, H., Solano-Heredia, E. (2015). Calidad del sueño en pacientes de 40 a 59 años. Revista de Especialidades Médico-Quirúrgicas, 20(3), 275-283.

Chauhan, A., Turchan, J., Pocernich, C., Bruce-Keller, A., Roth, S., Butterfield, D. A.,\&Nath, A. (2003). Intracellular human immunodeficiency virus Tat expression in astrocytes promotes astrocyte survival but induces potent neurotoxicity at distant sites via axonal transport. Journal of Biological Chemistry, 278(15), 13512-13519. doi: 10.1074/jbc.M209381200

Dabaghzadeh, F., Khalili, H., Ghaeli, P., \& Alimadadi, A. (2013). Sleep quality and its correlates in HIV positive patients who are candidates for initiation of antiretroviral therapy. Iranian Journal of Psychiatry, 8(4), 160-164.

Daniel, W. W. (1999). Biostatistics: A Foundation for Analysis in the Health Sciences 7th edition. New York: John Wiley \& Sons Inc.

Foster, S. B., Lu, M., Glaze, D. G., Reuben, J. M., Harris, L. L., Cohen, E. N., ... McMullen-Jackson, C. (2012). Associations of cytokines, sleep patterns, and neurocognitive function in youth with HIV infection. Clinical Immunology, 144(1), 13-23. doi: 10.1016/j.clim.2012.04.004

Garbarino, S., Lanteri, P., Durando, P., Magnavita, N., \& Sannita, W. G. (2016). Co-Morbidity, Mortality, Quality of life and the healthcare/welfare/social costs of disordered sleep: A Rapid Review. International Journal of Environmental Research and Public Health, 13(8). doi: 10.3390/ijerph13080831

Hastie, T., Tibshirani, R., \& Friedman, J. (2009). The Elements of Statistical Learning Data Mining, Inference, and Prediction. New York: Springer.

Hayashino, Y., Yamazaki, S., Takegami, M., Nakayama, T., Sokejima, S., \& Fukuhara, S. (2010). Association between number of comorbid conditions, depression, 
and sleep quality using the Pittsburgh Sleep Quality Index: Results from a population-based survey. Sleep Medicine, 11(4), 366-371.

Huang, X., Li, H., Meyers, K., Xia, W., Meng, Z., Li, C., ... \& Liu, S. (2017). Burden of sleep disturbances and associated risk factors: A cross-sectional survey among HIV-infected persons on antiretroviral therapy across China. Scientific Reports, 7(1), 3657. doi: 10.1038/s41598-017-03968-3

Irwin, M. R., Olmstead, R., \& Carroll, J. E. (2016). Sleep disturbance, sleep duration, and inflammation: A systematic review and meta-analysis of cohort studies and experimental sleep deprivation. Biological Psychiatry, 80(1), 40-52. doi: 10.1016/j.biopsych.2015.05.014

Jiménez-Genchi, A., Monteverde-Maldonado, E., Nenclares-Portocarrero, A., \& Esquivel-Adame, G. (2008). Reliability and factorial analysis of the Spanish version of the Pittsburg Sleep Quality Index among psychiatric patients. Gaceta Médica de México, 144(6), 491-496.

Johns, M. W. (1991). A new method for measuring daytime sleepiness: the Epworth Sleepiness Scale. Sleep, 14(6), 540-545.

Jordan, M. L., Perez-Escamilla, R., Desai, M. M., \& Shamah-Levy, T. (2016). Household food insecurity and sleep patterns among Mexican adults: Results from ENSANUT-2012. Journal of Immigrant and Minority Health, 18(5), 10931103. doi: 10.1007/s10903-015-0246-5

Jurado, S., Villegas, M. E., Mendez, L., Rodriguez, F., Loperena, V., \& Varela, R. (1998). La estandarización del Inventario de Depresión de Beck para residentes de la Ciudad de México. Salud Mental, 21(3), 26-31.

Koren, D., Dumin, M., \& Gozal, D. (2016). Role of sleep quality in the metabolic syndrome. Diabetes, metabolic syndrome and obesity: targets and therapy, 9, 281-310. doi: 10.2147/DMSO.S95120

Krystal, A. D.\& Edinger, J. D. (2008). Measuring sleep quality. Sleep Medicine, 9(Suppl 1), S10-S17. doi: 10.1016/s1389-9457(08)70011-x

Knutson, K. (2015). Sleep and pain: summary of the 2015 Sleep in America Poll. Sleep Health, 1(2), 85. doi: 10.1016/j.sleh.2015.02.005

Lorton, D., Lubahn, C. L., Estus, C., Millar, B. A., Carter, J. L., Wood, C. A., \& Bellinger, D. L. (2006). Bidirectional communication between the brain and the immune system: implications for physiological sleep and disorders with disrupted sleep. Neuroimmunomodulation, 13(5-6), 357-374. doi: 10.1159/000104864

Mahoney, J. J., De La Garza, R., Jackson, B. J., Verrico, C. D., Ho, A., Iqbal, T., \& Newton, T. F. (2014). The relationship between sleep and drug use characteristics in participants with cocaine or methamphetamine use disorders. Psychiatry Research, 219(2), 367-371. doi: 10.1016/j.psychres.2014.05.026

Norman, S. E., Chediak, A. D., Freeman, C., Kiel, M., Mendez, A., Duncan, R., Nolan, B. (1992). Sleep disturbances in men with asymptomatic human immunodeficiency (HIV) infection. Sleep, 15(2), 150-155.

Oshinaike, O., Akinbami, A., Ojelabi, O., Dada, A., Dosunmu, A., \& John Olabode, S. (2014). Quality of sleep in an HIV population on antiretroviral therapy at an urban tertiary centre in Lagos, Nigeria. Neurology Research International, 2014, 298703. doi: $10.1155 / 2014 / 298703$

Portacarrero, A. N.\& Genchi, A. J. (2005). Estudio de validación de la traducción al español de la Escala Atenas de Insomnio. Salud Mental, 28(5), 34-39.

Rodriguez, V., Magis, C., Casillas, J., Ramirez, H. V., Hernandez, G., Rentería, C. R., \& Gonzalez, A. (2012). Internal consistency and factorial structure of the Beck Depression Inventory (BDI) in Mexican HIV-positive patients. Poster at XIX International AIDS Conference July 22-27 2012 Washington, DC, USA. Retrieved from http://pag. aids2012. org/EPosterHandler. axd

Saberi, P., Neilands, T. B., \& Johnson, M. O. (2011). Quality of sleep: associations with antiretroviral nonadherence. AIDS Patient Care STDS, 25(9), 517-524. doi: 10.1089/apc.2010.0375

Sandoval-Rincon, M., Alcala-Lozano, R., Herrera-Jiménez, I., \& Jimenez-Genchi, A. (2013). Validation of the Epworth Sleepiness scale in Mexican population. Gaceta Médica de México, 149(4), 409-416.

Soldatos, C. R., Dikeos, D. G., \& Paparrigopoulos, T. J. (2000). Athens Insomnia Scale: validation of an instrument based on ICD-10 criteria. Journal of Psychosomatic Research, 48(6), 555-560.

Soldatos, C. R., Dikeos, D. G., \& Paparrigopoulos, T. J. (2003). The diagnostic validity of the Athens Insomnia Scale. Journal of Psychosomatic Research, 55(3), 263-267.

Strazza, M., Pirrone, V., Wigdahl, B., \& Nonnemacher, M. R. (2011). Breaking down the barrier: the effects of HIV-1 on the blood-brain barrier. Brain Research, 1399, 96-115. doi: 10.1016/j.brainres.2011.05.015

Tedaldi, E. M., Minniti, N. L., \& Fischer, T. (2015). HIV-associated neurocognitive disorders: the relationship of HIV infection with physical and social comorbidities. BioMed Research International, 2015, 641913. doi: 10.1155/2015/641913

Tello-Velasquez, J. R., Diaz-Llanes, B. E., Mezones-Holguin, E., Rodriguez-Morales, A. J., Huamani, C., Hernandez, A. V., \& Arevalo-Abanto, J. (2015). Poor quality of sleep associated with low adherence to highly active antiretroviral therapy in Peruvian patients with HIV/AIDS. Cadernos de Saúde Publica, 31(5), 9891002. doi: $10.1590 / 0102-311 \times 00010014$

Vosvick, M., Gore-Felton, C., Ashton, E., Koopman, C., Fluery, T., Israelski, D., \& Spiegel, D. (2004). Sleep disturbances among HIV-positive adults: the role of pain, stress, and social support. Journal of Psychosomatic Research, 57(5), 459463.doi: 10.1016/j.jpsychores.2004.03.003

Wibbeler, T., Reichelt, D., Husstedt, I. W., \& Evers, S. (2012). Sleepiness and sleep quality in patients with HIV infection. Journal of Psychosomatic Research, 72(6), 439-442. doi: 10.1016/j.jpsychores.2012.03.003

Wu, J., Wu, H., Lu, C., Guo, L., \& Li, P. (2015). Self-reported sleep disturbances in HIV-infected people: a meta-analysis of prevalence and moderators. Sleep Medicine, 16(8), 901-907. doi: 10.1016/j.sleep.2015.03.027 